\title{
Zbrodnia inkorporowana. O konwencji „paranoicznego gotyku” w Zbrodni z premedytacja Witolda Gombrowicza
}

Morderca? Łotrze! - zawotat. - Co ty sobie myślisz, wrzeszcząc na caly głos: morderca! Kto, u diabła, cię morduje czy też chce mordować?

J. Hogg, Wyznania usprawiedliwionego grzesznika przez niego samego spisane (1824)

Na początek spróbujmy krótko streścić jedno z najdłuższych i trzecie w kolejności opowiadanie debiutanckiego tomu Witolda Gombrowicza - Zbrodnię z premedytacja. Do ziemiańskiego dworku wieczorem przybywa bohater i pierwszoosobowy narrator - sędzia śledczy H. Chce tam załatwić „pewne sprawy majątkowe”, ale nie ma to związku z żadnym śledztwem, bo specjalnie na tę okazję nasz bohater bierze urlop. Na stacji kolejowej jednak nikt na niego nie czeka, mimo że był wcześniej zapowiadany. Zatem dojeżdża do dworku samodzielnie. Na miejscu chce się spotkać z Ignacym K., „obywatelem ziemskim”, człowiekiem poważnym, mężem i ojcem. Witany jest jednak bardzo chłodno, jakby mieszkańcy nie wiedzieli bądź zapomnieli o jego przyjeździe. Szybko dochodzi do wniosku, że w domostwie coś jest nie w porządku, coś dziwnego wisi w powietrzu. Nie potrafi określić co, a widomym znakiem zaburzeń staje się spocona dłoń, którą podaje mu córka właściciela dworu. Podczas wyjątkowo sztywnej kolacji prawda wychodzi na jaw: Ignacy K. nie żyje, umarł „dzisiejszej nocy” (jak należy rozumieć, kolacja odbywa się późnym wieczorem dnia następnego). Do śmierci doszło z przyczyn naturalnych, bohater „umarł na serce”. 
Sędzia śledczy H. ciągle ma jednak przekonanie, że coś jest niejasne. Na przykład ułożenie trupa na łóżku jest zbyt wyreżyserowane, a scena zbyt teatralna. Co więcej - główny bohater jest sędzią śledczym zajmującym się zabójstwami, a przed nim znajduje się trup. Czy to może być przypadek? Sędzia H. rekonstruuje zatem zdarzenia i dokonuje oględzin miejsca. Jedyną godna uwagi rzeczą okazał się „olbrzymi, zdechły karaluch”. Sędzia śledczy wie, że śmierć nastąpiła z przyczyn naturalnych (jest przecież specjalistą od oględzin zwłok), a jednak ma pewność, że popełniono morderstwo. Oznajmia zatem domownikom, że ojciec rodziny został uduszony (mimo że nie ma zewnętrznych objawów uduszenia). Następnie prowadzi śledztwo. Ustala, że małżonkowie śpią osobno oraz że ktoś zamknął drzwi od pokoju, w którym spał Ignacy K. Dochodzi również do wniosku, że domownicy zachowują się dziwacznie oraz że nie pałali do zmarłego szczególną sympatią. Przeciwnie, wręcz cieszą się z jego śmierci (co stanowi kolejny dowód na to, że coś nie jest w porządku). Śledczy ustala, że zbrodnia ma charakter „wewnętrzny”. Co więcej, trup „był w zmowie z bandą morderców" [Gombrowicz 2010: 72].

Coraz wyraźniej widać jednak, że sprawcą tej swoistej zbrodni naturalnej śmierci okazuje się Antoś, syn Ignacego K., który nie uronił żadnej łzy po śmierci ojca i ma do niego wyraźnie ambiwalentny stosunek. Śledczy przyciska go do muru, aż w końcu Antoś przyznaje się do winy (w bardzo dziwaczny sposób; nie mówi zatem: „ja to zrobiłem”, lecz „pojechałem”). H. jest zatem zadowolony, bo znalazł zbrodniarza-ojcobójcę. Jedyny problem polega na tym, że śmierć była naturalna, a na szyi denata nie ma śladów duszenia. Śledczy oznajmia te rewelacje Antosiowi, po czym ucieka korytarzem i wbiega do pokoju zmarłego, gdzie ukrywa się - tak właśnie - „w szafie” [Gombrowicz 2010: 82]. Z jej wnętrza przysłuchuje się dziwnym odgłosom, które następują zaraz potem. Po wydostaniu się z szafy dostrzega ślady uduszenia na szyi denata. Domyślamy się, że zostawił je Antoś. W ostatnich zdaniach tej pierwszoosobowej narracji dowiadujemy się, że syn przyznał się do uduszenia ojca i czeka na wyrok w sprawie zbrodni ojcobójstwa.

W klasycznej interpretacji tego opowiadania, pióra Kazimierza Bartoszyńskiego, zatytułowanej znacząco O nieważności „tego, 
jak było naprawdę" - punkt wyjścia i dojścia stanowi diagnoza narracyjna i genologiczna. Po pierwsze zatem „ta, raczej niezaangażowana relacja, wydaje się być przeznaczona dla odbiorców bliskich czasowo, przestrzennie i społecznie narratorowi” [Bartoszyński 1984: 386]. Badacz zauważa także podobieństwo „metod narracji zastosowanych $\mathrm{w}$ Zbrodni... z dobrze znanymi tradycjami dziewiętnastowiecznego gawędziarstwa literackiego" [Bartoszyński 1984: 386]. Przede wszystkim jednak Zbrodnia z premedytacja wykorzystuje poetykę powieści detektywistycznej - z jej najbardziej rozpoznawalnymi cechami, takimi jak jedność czasu i miejsca, ograniczoną liczbą bohaterów czy swoistym „efektem zaskoczenia”. Koniec końców, zauważa Kazimierz Bartoszyński w ostatnich słowach swego studium, „rzekomy «kryminał» okazuje się - w wielorakim sensie - gatunku tego odwróceniem i parodią" [Bartoszyński 1984: 395]. Istotnie, opowiadanie wydaje się pod wieloma względami zbyt ... szalone, by można je uznać za klasyczną realizację gatunku. Jednocześnie Bartoszyński wskazuje na literackie antecedencje koncepcji, wskazując na tradycje powieści gotyckiej, a zwłaszcza te utwory, które czynią

[...] swą osią manichejskie napięcie zła i dobra, wszechobecną dwuznaczność natury ludzkiej upostaciowaną np. w osobie Cardillaca z powieści Hoffmana, w Dorianie Grayu z powieści Wilde’a czy $\mathrm{w}$ dwoistym istnieniu dr. Jekylla i Mr Hyde’a z utworu Stevensona. [Bartoszyński 1984: 392-393].

Związki i genologiczne gry z konwencją powieści detektywistycznej oraz intertekstualne nawiązania to locus comunnes wielu interpretacji.

Innym wyraźnym miejscem wspólnym jest wątek edypalny. Można by rzec, że występuje on w dwóch łączących się wersjach: intertekstualnej, eksponującej analogię do motywu antycznego [Szymutko 1993: 241-242] oraz jego wersje freudowską, z którą Gombrowicz może prowadzić grę [Margański 2001: 85]. Trudno nie zgodzić się z tymi diagnozami, a jednocześnie trudno nie dorzucić jednego elementu, który znacząco dookreśla wszystkie 
powyższe intuicje, a zarazem uspójnia sam kształt narracji $Z$ brodni $z$ premedytacją. Tym pojęciem, skądinąd kluczowym w teorii Eve Kosofsky Sedgwick, jest paranoja. W znaczeniu najbardziej potocznym oznaczałaby ona przecież dostrzeganie czegoś, czego nie ma czy raczej dostrzeganie nieistniejących związków pomiędzy zdarzeniami. A dokładnie tak zachowuje się sędzia śledczy H. W sensie fabularnym „efekt zaskoczenia”, a tym samym ostateczne potwierdzenie, że mamy do czynienia ze swoistą narracją $\mathrm{w}$ paranoicznym stylu, otrzymujemy w ostatnim akapicie opowiadania, który niejako wywraca do góry nogami sens opowieści. Sędzia powiada:

Kiedy po długiej godzinie drżący i spotniały wydostałem się z szafy, gwałt i przemoc panowały wśród pomieszanej pościeli, ciało rzucone było na ukos przez zmiętą poduszkę, a na szyi zmarłego widniały wyraźne odciski wszystkich dziesięciu palców. Lekarze-eksperci krzywili się wprawdzie na te odciski, mówili, że coś z tym jest nie tak, jak być powinno - jednakże odciski te, łącznie z wyraźnym przyznaniem się zbrodniarza na rozprawie, uznane zostały za dostateczną podstawę. [Gombrowicz 2010: 83]

Dzięki ostatniemu akapitowi rozumiemy, że można, a nawet należy, czytać Zbrodnię z premedytacja jako spowiedź prawdziwego sprawcy potencjalnej zbrodni - czyli sędziego śledczego, który za pomocą psychologicznych trików oraz moralnych szantaży doprowadza Antosia do internalizacji winy i potencjalnej kary śmierci po zapowiadanym procesie w sądzie Jeśli ktoś tu jest winny zbrodni z premedytacją to sam sędzia śledczy, który wyraźnie chce doprowadzić do skazania młodego mężczyzny. W ten sposób całe opowiadanie przeistacza się w narrację prześladowczą (gdzie prześladowcą jest sędzia, a prześladowanym - Antoś) w wyraźnie paranoicznym stylu. Paranoja niejako uspójnia tę narrację i uzupełnia dotychczasowe interpretacje ${ }^{1}$. Znaczenie „paranoicznego gotyku”

1 Por.: „Natomiast niedopasowanie zachowań do okoliczności wywołuje wrażenie, iż otaczający świat przestał być rzeczywisty, jak dzieje się to z Józiem i z bohate- 
dla teorii queer ma znaczenie niebagatelne. Przypomnijmy krótko kilka podstawowych idei. Punktem wyjścia rozważań Sedgwick jest zestawienie wczesnych powieści gotyckich z myślą Zygmunta Freuda, a zwłaszcza ze studium Psychoanalityczne uwagi o autobiograficznie opisanym przypadku paranoi z 1911 roku. Tam właśnie pojawia się teoria paranoi wywiedziona głównie $\mathrm{z}$ interpretacji autobiograficznych wspomnień Daniela Paula Schrebera pod tytułem Pamiętniki nerwowo chorego. Na język polski tekst ten przetłumaczono dopiero $\mathrm{w} 2006$ roku [Schreber 2006], ale na początku wieku Xx wieku był on bardzo głośny - i to był powód, dla którego zajął się nim sam Freud. Mistrz hermeneutyki podejrzeń w swej bardzo skrupulatnej interpretacji dochodzi do wniosku, że wyparcie przez podmiot homoseksualnego pożądania skutkuje manią prześladowczą i w tym sensie, można powiedzieć, paranoja jest swoistą , homoseksualną chorobą.. Sedgwick nie traktuje tej hipotezy apologetycznie czy metateoretycznie, lecz jako punkt wyjścia własnych krytycznych rozważań. Wskazuje na podobieństwo pomiędzy powieściami gotyckimi a przypadkiem Schrebera, do tego stopnia wyraziste, że niektóre miejsca fabuły można rzutować na Wspomnienia nerwowo chorego. Uznaje, nieco odwrotnie niż Freud, a mając w pamięci cały korpus tekstów krytycznych, zwłaszcza pióra Guya Hocquenghema [Hocquenghem 1978], iż przypadek Schrebera pokazuje, że „paranoja to psychoza, która uwypukla mechanizm homofobii” [Sedgwick 1985: 91].

W ten sposób powieść gotycka staje się uprzywilejowanym gatunkiem, który niejako mieści w sobie możliwość opisu nowych relacji pomiędzy mężczyznami, w tym również erotyzację niektórych męskich relacji homospołecznych. W „pre-genderowej” ramie teoretycznej na te kwestie zwracała również uwagę Maria Janion w eseju Forma gotycka Gombrowicza:

rami Zbrodni” [Łapiński 1997: 54]. „Nic tu na wiarę nie zasługuje, wszystko - by wrócić do punktu wyjścia obecnych rozważań - jest w Zbrodni ... pozorem: narrator na pozór przemawiający rozważnie, z dystansem i w sposób gawędowy, okazuje się reżyserem głęboko zaangażowanym w zdarzenia przedstawione" [Bartoszyński 1984: 395]. Ponadto w istotny sposób do Zbrodni z premedytacją odnoszą się: Jarzębski 1982 (zwłaszcza rozdział Obrzęd i zbrodnia), Falkiewicz 1984; Kijowski 1984, Legierski 1996. 
Powieść gotycka odegrała w tym dziele szczególną rolę. Największą tajemnicą, którą odkrywała i której dotykała, była przewrotność Losu i dwoistość natury ludzkiej, najczęściej upostaciowana w bohaterze i jego sobowtórze, objawiająca się w obłędzie, opętaniu, w niedającym się do końca racjonalnie wytłumaczyć nasileniu - niemal nadprzyrodzonym rozpętanych złych instynktów i namiętności, zwłaszcza już erotycznych. Była to więc Tajemnica Zbrodni i Zła - i tajemnica fatalnego pociągu, jaki nieoczekiwanie dla siebie samych odczuwają do siebie istoty ludzkie [... ]. [Janion 1975: 169-170]

Nie bez znaczenia jest jednak płeć tych istot ludzkich. Wśród centralnych motywów wczesnego gotyku (który jest podobny do „przypadku Schrebera”) Sedgwick wymienia zwłaszcza ten charakterystyczny motyw, stanowiący wręcz jądro gotyku, zgodnie z którym jeden mężczyzna prześladuje innego mężczyznę, często czuje się w stosunku do niego wręcz umysłowo przezroczysty i staje się przedmiotem jego kompulsywnych działań ${ }^{2}$ [Sedgwick 1985:91].

W tym miejscu interpretacji warto dostrzec jak wiele charakterystycznie paranoiczno-gotyckich motywów można odnaleźć w debiucie Witolda Gombrowicza. Zwłaszcza motyw, w którym jeden mężczyzna (bądź grupa mężczyzn) prześladuje innego. Tak się niewątpliwie dzieje właśnie w Zbrodni z premedytacja - i to w charakterystycznie paranoicznym stylu. Podobnie rzecz wygląda w Tancerzu mecenasa Kraykowskiego - młody mężczyzna prześladuje tutaj starszego i to, po kilku akapitach, mocno paranoicznie. To główna oś fabularna tego tekstu. Prześladowanie „nieparanoiczne” pojawia się w Krótkim pamiętniku Jakuba Czarnieckiego ${ }^{3}$. Niemal paradygmatycznie paranoidalny „zły obiekt” [Laplanche 1996: 205], pod postacią oksymoronicznego Białego Murzyna, który prześladuje bohatera, odnajdziemy w opowiadaniu pod

2 Dokładniej: „[...] each is about one or more males who not only is persecuted by, but considers himself transparent to and often under compulsion of another male" [Sedgwick 1985: 91]. 
„freudowskim” tytułem Na pięć minut przed zaśnięciem". Paranoiczne prześladowania przez grupę mężczyzn to również główny motyw kończącego zbiór opowiadania Zdarzenia na brygu Banbury (czyli aura umystu F. Zantmana).

Gotyk jako klucz do twórczości i osobowości Witolda Gombrowicza wskazywała rzecz jasna nade wszystko Maria Janion,


do rozumienia wczesnej twórczości Gombrowicza, zwłaszcza jeśli przywołamy cechy i funkcje powieści gotyckiej wyszczególnione przez Sedgwick. Spośród kwestii, które omawia autorka, dwie szczególnie łączą się z Pamiętnikiem z okresu dojrzewania. Po pierwsze gotyk daje wgląd w indywidualną i rodzinną psychologię poprzez zarysowywanie edypalnego ksztaltu rodziny. Po drugie natomiast gotyk wskazuje na napięcia klasowe, gdzie arystokracja - mówimy o warunkach brytyjskich - odgrywa rolę rodzica, którego przeznaczeniem jest być zrzuconym $\mathrm{z}$ tronu [Sedgwick 1985: 93]. Nietrudno zauważyć, jak mocno te kwestie rezonują w Pamiętniku. Indywidualna psychologia w kontekście krytykowanego edypalnego kształtu rodziny pojawi się najwyraźniej w Krótkim pamiętniku Jakuba Czarnickiego oraz w następującej po nim Zbrodni z premedytacja, a groteskowo przedstawione napięcia klasowe czy niemal stanowe w Biesiadzie u hrabiny Kottubaj. Oba wątki zresztą wyraźnie się zazębiają.

Powróćmy do Freuda i jego teorii paranoi. Po dokładnej analizie „przypadku Schrebera” autor przechodzi do swoistego uogólnienia, czyli zarysowania tego, co nazywa „mechanizmem paranoi”. Główna idea daje się streścić do stwierdzenia, iż „charakter paranoiczny polega na tym, że [podmiot] w celu odparcia homoseksualnej fantazji życzeniowej reaguje tego rodzaju manią prześladowczą" [Freud 1996: 147]. W ten sposób okazuje się, że wszystkie znane formy paranoi można przedstawić jako sprzeciw wobec niewyrażalnego zdania „Kocham go” czy też dokładniej, jak z filologiczną precyzją pokazuje Freud, stwierdzenia: „Ja (męż-

4 W Bakakaju zamienionym na Przygody.

5 „Forma powieści gotyckiej stała się dla Gombrowicza narzędziem zdobywania samoświadomości” [Janion 1975: 183]. 
czyzna) kocham go (mężczyznę)" [Freud 1996: 150]. Jednym ze sposób oparcia się temu zdaniu (i kryjącemu się pod nim afektowi) jest mania prześladowcza, której wewnętrzny komunikat przeciwstawia się orzeczeniu zdania i realizuje jako "Ja nie kocham go przecież go nienawidzę" [Freud 1996: 150]. Dalej Freud stwierdza:

Mechanizm formowania się symptomu w paranoi wymaga, by postrzeżenie wewnętrzne, uczucie, zostało zastąpione przez postrzeżenie z zewnątrz. Tym samym zdanie „Przecież go nienawidzę” za sprawą projekcji zmienia się w inne: „On mnie nienawidzi (prześladuje), to zaś usprawiedliwia nienawiść”. [Freud 1996: 150]

W ten sposób ostatecznie zdanie „kocham go”, pod wpływem pracy paranoi, zamienia się $\mathrm{w}$ „Przecież go nie kocham - przecież go nienawidze - ponieważ on mnie prześladuje" [Freud 1996: 150]. I to właśnie zdanie jest wypowiadalne i zewnętrzne w stosunku do niewypowiadalnego, nieświadomego pierwowzoru. Tym samym zdanie „nienawidzę go, ponieważ on mnie prześladuje” to paranoiczny symptom zdania „kocham go". Freud konkluduje „Obserwacja ta nie dopuszcza żadnych wątpliwości co do tego, że prześladowcą nie jest nikt inny, tylko ktoś ongiś kochany” [Freud 1996: 150].

Sedgwick, rzecz jasna nie przyjmuje rozstrzygnięć Freuda na wiarę, lecz doceniając jego hermeneutyczne umiejętności, traktuje gotycko-paranoiczne narracje jako uprzywilejowane fabuly, które odsłaniają mechanizm homofobii. A homofobię należy tu rozumieć jako uniwersalny nowoczesny mechanizm regulowania zależności pomiędzy mężczyznami. $Z$ tego punktu widzenia spróbujmy raz jeszcze podejść do analizy i interpretacji Zbrodni $z$ premedytacją. Zacznijmy zatem czytać podejrzliwie, wyszukując paranoiczne symptomy i niespójności.

Już w pierwszym akapicie opowiadania, w nieco gotyckiej scenerii, zaznaczony zostaje sygnał charakterystycznego niepokoju:

[...] i oto przez cztery godziny tłukę się przez pola w nocy, w ciszy, w czasie odwilży. Trzęsę się w miejskim palcie, szczę- 
kając zębami, patrzę na plecy furmana i myślę - tak nadstawiać pleców! Tak wiecznie, często w bezludnej okolicy, być odwróconym plecami i zdanym na wszelki kaprys siedzących z tyłu! [Gombrowicz 2010: 40-41 - wyróż. B.W.]

Tak oto, w gotyckiej atmosferze - sędzia $\mathrm{H}$. zaraz zacznie walić w drzwi zanurzonego w ciemnościach dworu - pojawia się charakterystyczny obraz projekcji lęku. Siedzieć odwróconym do kogoś plecami i to przez długi czas. Najwidoczniej dla sędziego taki rodzaj zachowania nie jest możliwy. Postawa ta oznacza narażanie na potencjalny nagły atak. Skoro zatem sędzia śledczy tego nie potrafi, oznacza to, że już wcześniej został zaindukowany paranoicznym lękiem prześladowczym.

Domostwo, zgodnie z gotycką konwencją (na myśl przychodzą choćby Wichrowe wzgórza, ale też wszelkie możliwe zamczyska), pozostaje wyjątkowo niegościnne. W końcu jednak dobijanie się do drzwi przynosi sukces. Zaraz potem sędzia poznaje siostrę Antosia. Nie wiemy, ile siostra ma lat (opowiadanie tego nie precyzuje), wiemy natomiast, że ma na imię Cecylia. Rozumiemy też, że istnieje jakiś rodzaj homologii pomiędzy rodzeństwem. Siostra Antosia jest młodą kobietą, a sędzia czuje się niejako zaatakowany jej kobiecością.

- Moja siostra.

- A, bardzo mi miło! I rzeczywiście - bardzo miło, gdyż kobiecość, choćby nawet i bez żadnych ubocznych zamiarów, kobiecość, powiadam, nigdy nie zawodzi. Ale ręka, którą mi podała, jest spocona - kto kiedy widział podawać mężczyźnie spoconą rękę? - a kobiecość sama, pomimo wdzięcznej twarzyczki, jakaś nie wiem, spocona i obojętna, bez żadnej reakcji, rozmamlana i nieuczesana. [Gombrowicz 2010: 42]

Kobiecość jest rozumiana przez sędziego jako uosobienie mieszczańskiej łagodności, das ewig Weibliche, która ma jednak coś potencjalnie ukryć, stanowi jakieś zakłócenie ładu (a pamiętajmy, że „paranoja jest antycypacyjna” [Sedgwick 2014: 5]). Jednocześnie jednak kobiecość siostry może poprzez działanie homolo- 
gii odnosić się do nienazwanej (ale być może istotnej) męskości Antosia. W istocie zarysowuje się tu męsko-kobieco-męskie „pragnienie trójkątne”, w którym Cecylia spełnia funkcję pośrednika. Widzimy też, że kobiecość percypowana przez sędziego ma skazę, jest wręcz abiektalna w rozumieniu Kristevej (zwłaszcza gdy przypomnimy sobie, że właśnie wydzieliny ciała - jak ślina czy pot można rozumieć jako swoisty model abiektu, czyli czegoś, co było częścią podmiotu, a następnie być nią przestało - i zamieniło się $\mathrm{w}$ coś odrażającego). Zgodnie z rozpoznaniami analityczki skalanie to „rytuał wspomagający fobię i psychozę” [Kristeva 2007: 63]. Zatem ta abiektalna kobiecość „zaatakowała” naszego sędziego.

Z kolei podczas kolacji sędzia ma uczucie (własnej i cudzej) nieadekwatności. W tym scenariuszu sędzia znajduje się w pozycji paranoicznej ${ }^{6}$. Próbuje zrozumieć przyczyny nienaturalnego zachowania trójki współbiesiadników, ale nie potrafi znaleźć odpowiedniego wzoru. W związku z czym - w neurotycznym odruchu - zaczyna szukać przyczyn w sobie, a nie w sytuacji zewnętrznej. Zauważmy, że tutaj mamy jeszcze do czynienia z niejako „zdrową” reakcją: wszyscy dookoła zachowują się dziwnie teatralnie - z powodu śmierci patriarchy; sędzia śledczy nie jest wtajemniczony w sytuację, w związku z czym zaczyna poszukiwać jej przyczyn w sobie. W języku nieco bardziej psychoanalitycznym można powiedzieć, że internalizuje własną projekcję. Jednak bez względu na język warto zauważyć, że już tutaj, na początku opowiadania, pojawia się dialektyka „wnętrza” i „zewnętrza” tak silnie obecna w wielu opowiadaniach z Pamiętnika (w tym również w dalszych partiach Zbrodni z premedytacja) i tak istotna dla Freuda jako analityka „przypadku Schrebera”. Przypomnijmy bowiem już wcześniej przywoływany fragment pracy ojca psychoanalizy: „Mechanizm formowania się symptomu w paranoi wymaga, by postrzeżenie wewnętrzne, uczucie, zostało zastąpione przez postrzeżenie z zewnątrz" [Freud 1996: 150].

W opowiadaniu to, co zewnętrzne (według „aury umysłu” sędziego H.) to sztuczność czy też teatralność zachowania miesz-

6 „Pozycja paranoiczna” to pojęcie Melanie Klein; tu jednak używam go w sensie zdroworozsądkowym. 
kańców dworu. A także teatralność ułożenia zwłok na łóżku. Jest ona (ciągle w obrębie „aury umysłu” sędziego H.) niemal agresywna, a w każdym razie atakująca.

Przyglądałem się kwiatom, a potem patrzyłem znów w twarz zmarłemu, lecz nic mi nie przychodziło do głowy, jak tylko ta jedna myśl, dziwnie uporczywa, że to jakaś - z góry ułożona, teatralna scena. Wszystko wyglądało, jakby wyreżyserowane - tam trup, dumny, nietykalny, spoglądający zamkniętymi oczami obojętnie w sufit, obok - bolejąca wdowa, tu - ja, sędzia śledczy, na klęczkach, jak zły pies, któremu założono kaganiec $[. .$.$] - Co to jest - pomyślałem z wolna - kto to$ tak wyreżyserował? Ja jestem człowiek zwykły, pospolity nie nadaję się do takich występów... [Gombrowicz 2010: 50, wyróż. - B.W.].

Teatralność rzeczywistości jest w paranoicznym stylu - atakująca i zagrażająca, ale jednocześnie to właśnie sędzia używa wobec siebie metafory, która opisuje go jako zakneblowanego agresora i prześladowcę („zły pies, któremu założono kaganiec”). Kto więc komu zagraża? Kto jest prześladowcą, a kto prześladowanym? Sytuacja nieco bardziej się wyklaruje, gdy teatralność, do tej pory „zewnętrzna”, wejdzie do „wewnątrz” bohatera:

Nie radzę... Do diabła! - zastanowiłem się nagle - co to za głupstwa! Skąd mi się to wzięło? Czyżbym się zgrywał? Skąd u mnie taka sztuczność, afektacja - przecież ja na ogól jestem zupełnie inny - czy ja się od nich zaraziłem? Co to jest odkąd tu przyjechałem, wszystko we mnie wypada sztucznie i pretensjonalnie, jakby przedstawiane przez marnego aktora. Zupełnie się zatraciłem w tym domu - okropnie się zgrywam. Hm - szepnąłem i znowu nie bez pewnej teatralnej pozy (jakbym już był wciągnięty w grę i nie mógł powrócić do normy) - nie radzę nikomu... Nie radzę nikomu robić ze mnie demona, bo gotów byłbym przyjąć zaproszenie... [Gombrowicz 2010: 50, wyróż. - B.W.] 
Gdy zatem spojrzymy na przebieg sytuacji obiektywnie, to dostrzeżemy, że wygląda ona całkowicie normalnie: Antoni, Cecylia i ich matka zachowują się może dość sztucznie, ale z obiektywnego powodu: śmierci ojca i męża oraz konieczności wchodzenia w interakcje społeczne w sytuacji żałoby. Ich sztuczność może być też skutkiem (ten motyw powraca w opowiadaniu raz po raz jako zarzut ze strony sędziego) pewnej arystokratycznej „formy”, czyli wyższości i protekcjonalności - co jest skądinąd, wedle Sedgwick, charakterystycznym dla gotyku uwypukleniem napięć klasowych (które mocniej powrócą w następnym opowiadaniu zbioru, czyli Biesiadzie u hrabiny Kottubaj, tu występują tylko na zasadzie antecedencji). Jednak ta obiektywnie „normalna” sytuacja w paranoicznej narracji sędziego wygląda całkowicie inaczej: sztuczność atakuje i prześladuje, a następnie wkracza do wnętrza sędziego. Być może najlepiej zdradzają paranoiczną narrację właśnie metafory, których sędzia używa do opisu samego siebie: „zły pies” i „demon”. W obu wypadkach są to metafory oznaczające prześladowcę, a nie prześladowanego.

Szczególnie ciekawy jest ten nagły passus: „Nie radzę nikomu robić ze mnie demona, bo gotów byłbym przyjąć zaproszenie...”. Po pierwsze dlatego, że nasz bohater istotnie „powraca” jak swoisty demon - jest sędzią śledczym, a zatem rodzajem detektywa w sytuacji, gdy w domostwie pada (naturalny) trup. Po drugie ta metafora ma bardzo gotycką wymowę i nieco przypomina aurę analizowanej przez Sedgwick powieść Jamesa Hogga Wyznania usprawiedliwionego grzesznika przez niego samego spisane (to m.in. opowieść o spotkaniach z diabłem). Przypomnijmy również, że metafory gotyckie na początku xx wieku bardzo często otaczały niewyrażalną homoseksualność. Na przykład Alfred Adler rozpoczynał swoją książkę Homoseksualizm, wydaną w Polsce w 1935 roku, od zdania „Zagadnienie homoseksualizmu wyłania się w społeczeństwie jak straszliwy upiór” [Adler 1935: 5]. Przypomnijmy też - tylko na zasadzie nagłego przemieszczenia, freudowskiego Verschriebung - że Ignacy Fik w swym słynnym tekście polemicznym Literatura choromaniaków, w którym odnosił się między innymi do debiutu Gombrowicza - mówił o „literaturze demonokratycznej” [Fik 1961: 126], co miało konotować nadmierne roz- 
buchanie seksualne tekstów i ich twórców. Jak pisze „[t]a wstawka zgłoski «no» w ostatnim słowie nie ma być pomyłką drukarską, ale ma dać sugestię poprzez etymologię, że piszą tę literaturę demoni i ona sama pełna jest demonów" [Fik 1961: 126]. Pamiętajmy też, że Gombrowicz, jako jedyny z wymienionych w artykule pisarzy, odniósł się do paszkwilu, chociaż pod pseudonimem.

Powróćmy do opowiadania, czyli paranoicznej narracji sędziego H. czytanej przez freudowski „przypadek Schrebera”. Jedno z jego najważniejszych ustaleń jest takie, że mamy oto do czynienia ze zbrodnią „wewnętrzną”, w odróżnieniu od „zewnętrznej", co jednocześnie stanowi jeden z leitmotivów w Pamiętniku z okresu dojrzewania. Jak jednak należy rozumieć ten kluczowy dla rozpoznań sędziego przymiotnik? Jak kilka innych istotnych słów w opowiadaniu - jednocześnie dosłownie i metaforycznie, opierając się na zmianach kontekstów, które modyfikują znaczenia słów, a tym samym oświetlają się nawzajem. Najpierw zatem okazuje się, że: „dom był wyjątkowo «wewnętrzny», która to wewnętrzność uwidacznia się głównie w wacie okiennej i wyszczerbionym spodku, z zeschłym, jeszcze z lata, plasterkiem trucizny na muchy" [Gombrowicz 2010: 61]. I w tym właśnie „wewnętrznym” domu popełniono „wewnętrzne” morderstwo: „[... ] zbrodnia, jak można uważać za ustalone w drodze badania, była wewnętrzna [...]" [Gombrowicz 2010: 62]. Co to oznacza? Z dalszych rozważań sędziego wynika, że zbrodnia popełniona przez lokaja w celach rabunkowych byłaby „zewnętrzna”, natomiast samobójstwo czy ojcobójstwo - „wewnętrzne”. W tym szaleństwie jest metoda: klasowa dystynkcja. Koniec końców jednak zostaje ona przekroczona, bo sędzia dochodzi do wniosku: „Właściwa zbrodnia dokonywa się zawsze w duszy. Zewnętrzne szczegóły... mój Boże!” [Gombrowicz 2010: 68]. Zewnętrzne szczegóły oczywiście nie są istotne. I tu następuje przykład, w którym siostrzeniec zabija wujka szpilką, myląc jego plecy z kapeluszem kuzynki. Prawda zbrodni zamyka się w jej „wewnętrzności” czyli w tym, że jest „psychiczna” [Gombrowicz 2010: 68] oraz „duchowa” [Gombrowicz 2010: 68]. Przedstawiane są kolejne groteskowe przykłady, które wyglądają jak parodia motywów freudowskich. Albo też inaczej: wyglądają tyleż parodystycznie, co paranoicznie. 
We freudowskiej interpretacji wspomnień Schrebera dystynkcja wnętrza i zewnętrza odgrywa rzecz jasna kluczową rolę, w istocie bowiem dotyczy sposobu działania projekcji. W teoretycznej części swoich rozważań, części zatytułowanej $O$ mechanizmie paranoicznym, Freud dokonuje wręcz zwrotu w swym dotychczasowym myśleniu:

[...] właściwy proces wyparcia polega na oderwaniu się libido od osób wcześniej kochanych - i od rzeczy. Proces ten przebiega w ciszy; nie otrzymujemy żadnej informacji na ten temat; o tym, że on zachodzi, wnioskujemy na podstawie występujących w jego wyniku zjawisk. Tym, co hałaśliwie zwraca naszą uwage, jest natomiast proces uzdrowienia, który zawraca wyparcie i z powrotem doprowadza libido do porzuconych przez nie osób. W wypadku paranoi proces ten spełnia się na drodze projekcji. Nie mieliśmy racji, kiedy stwierdziliśmy, że doznanie wewnętrznie tłumione jest projektowane na zewnątrz; teraz rozumiemy, że to raczej to, co wewnętrznie zniesione, powraca z zewnątrz. [Freud 1996: 156, wyróż. - B.W.]

W Pamiętnikach nerwowo chorego Daniela Paula Schrebera głównym prześladowcą, złym obiektem i przedmiotem manii jest doktor Flechsig, jego własny lekarz. Podejrzliwy interpretator, Freud, dostrzega, że to nie jest przypadek ani zwykłe przeniesienie. Flechsig, terapeuta choroby Schrebera, powinien być przezroczysty - jak narrator w powieści personalnej, jak służka-opowiadaczka w Wichrowych wzgórzach Emily Bronte - ale wcale nim nie jest. Schreber znał Flechsiga w okresie poprzedzającym epizody chorobowe. I odczuwał w stosunku do niego homoseksualne pożądanie, a z czasem radykalne wyparcie, które zaowocowało zapaścią, psychiczną katastrofą. Libido Schrebera odłącza się od osoby Flechsiga, ale „za nim podąża zaraz mania, która z powrotem doprowadza libido do Flechsiga ( $\mathrm{z}$ negatywnym oznakowaniem jako cechą dokonanego wyparcia) i w ten sposób znosi wyparcie” [Freud 1996: 157-158]. Libido Schrebera powraca zatem niczym demon do swego obiektu, a on czuje się przez ten obiekt prześladowany. 
Jak widać, interpretacja Freuda bardzo przypomina narrację detektywistyczną w gotyckiej aurze. $\mathrm{Z}$ tego punktu widzenia jest być może wyraźniejsze, dlaczego wczesne powieści gotyckie zestawiane z krytycznie analizowanym „przypadkiem Schrebera” (do którego są tak podobne), stają uprzywilejowaną narracją opowiadającą o homospolecznych relacjach między mężczyznami w sytuacji instytucjonalizującej się homofobii. Zwłaszcza że również dziś homofobię można rozpatrywać jako formę paranoi poprzez podobieństwo strukturalne opierające się na permanentnej podejrzliwości. Przypadek „sędziego H.” można czytać komparatystycznie z freudowską interpretacją choroby „prezesa senatu Schrebera" [Freud 1996: 163]. A zacząć należy zapewne od poetyki narracji. Pamiętniki nerwowo chorego Schrebera to pierwszoosobowa narracja nastawiona na wyjaśnienie, usprawiedliwienie i wyjawienie prawdy. Narracja Zbrodni z premedytacja jest bardziej skomplikowana. To również narracja pierwszoosobowa, nastawiona na wyjaśnienie, usprawiedliwienie i wyjawienie prawdy. Nie jest jednak znany adresat tej wypowiedzi (głównie monologu) - może nim być Bóg, mogą jakieś zainteresowane osoby, również bardzo oddalone czasowo.

Dywagacje na temat „wewnętrzności” morderstwa i przykłady obrazujące ten aspekt, które zmierzają do opowiedzenia o mordzie „psychicznym” czy „duchowym” - na zasadzie przeniesienia - zdają się opowiadać o jego własnym doświadczeniu destrukcji, które w analizie Freuda odpowiadają dewastacji wewnętrznej Schrebera po wyparciu. „Koniec świata to projekcja tej katastrofy wewnętrznej; subiektywny świat chorego zapadł się $\mathrm{w}$ chwili, gdy pacjent odebrał mu miłość, jaką go ongiś darzył" [Freud 1996: 155]. Innymi słowy: doświadczenie końca świata to projekcja wewnętrznej katastrofy, po tym, jak odebrał sobie i światu obiekt swej miłości.

W przypadku sędziego $H$. najważniejszym przeniesieniem jeśli podążamy za Freudem - jest przeniesienie śmierci Ignacego K. (który nie został zamordowany) na siebie samego (on - we własnym odczuciu - został). Innymi słowy dokonuje się tutaj „inkorporacja zbrodni” [Sedgwick 1985: 97-117], by użyć parafrazy tytułowej formuly Sedgwick z rozdziału poświęconego analizie Wyznan usprawiedliwionego grzesznika Hogga. Sędzia, mówiąc o śmierci 
Ignacego K., raz po raz przesuwa znaczenia (właśnie na zasadzie freudowskiego „przeniesienia”), bo ma na myśli siebie. W celu, jedynie hipotetycznego, udowodnienia tej tezy przyjrzyjmy się dwóm słowom-fetyszom, które powracają w toku narracji. Pierwsze z nich to - „serce”, a drugie - „karaluch”.

„Serce” po raz pierwszy pojawi się w rozmowie sędziego $\mathrm{z}$ wdową.

Zmarły leży na łóżku - tak, jak umarł - tyle tylko, że ułożono go na wznak. Twarz sina, obrzękła, świadczyła o śmierci wskutek uduszenia, jak zwykle przy atakach sercowych.

- Uduszony - szepnąłem, choć wiedziałem dobrze, że atak sercowy.

- To serce, serce, panie... Umarł na serce...

- $\mathrm{O}$, serce umie czasami zadusić... umie - rzekłem ponuro.

[Gombrowicz 2010: 48-49]

W toku opowieści sędziego wielofunkcyjność słowa „serce” jest wykorzystywana niczym chiazm [Ziomek 1990: 222-223]. Po pierwsze zatem sędzia, co oczywiste, gra w tym fragmencie (i nie tylko tym) na dosłownym i metaforycznym sensie tego słowa. „Serce” dosłownie rozumiane oznacza biologiczny organ ciała, którego dysfunkcja może zabić i która zabiła (wedle wszelkich danych) ojca rodziny; z drugiej strony „serce” to metaforyczny ośrodek uczuć, który również może zabić (tak się dzieje, gdy „umieramy z miłości”). Emocjonalne napięcie w obrębie tego krótkiego dialogu wynika właśnie z dwuznaczności słowa „serce”, świadomie wykorzystywanej przez sędziego. Mówiąc jeszcze inaczej „serce” czasami bywa metaforą, a czasami metonimią. Za każdym razem, gdy słuchamy sędziego, musimy pamiętać, że „serce” może - w toku jego narracji - być albo jednym albo drugim. A w związku z tym - może zabić z różnych powodów całkiem różne osoby.

Przyczyna śmierci Ignacego K. jest bowiem skonstruowana bardzo specyficznie. Umarł on bowiem „na serce”. Ten sam „wewnętrzny” skutek mogą jednak wywołać dwie różne przyczyny: naturalne, wtedy mamy do czynienia $\mathrm{z}$ atakiem serca bez żadnych 
„zewnętrznych” objawów, bądź uduszenie, którego „zewnętrzne” ślady można dostrzec. Widoczne objawy zabijają dosłowne serce; brak zewnętrznych objawów może zabić serce metaforyczne. Co więcej - nie zawsze wiadomo kto jest przedmiotem narracji, innymi słowy, o czyje serce chodzi. W ostatnim wersie cytowanego dialogu („serce umie czasami zadusić... umie”) może chodzi równie dobrze o „serce” denata, jak o serce samego sędziego. W paranoicznie rozchwianej narracji ta niepewność dotycząca właściwego kształtu sytuacji komunikacyjnej powraca wielokrotnie. I wydaje się być to przez autora skrupulatnie zaplanowane.

„Była to fizyczna i medyczna oczywistość, był to pewnik - nikt go nie zamordował dla tej prostej i decydującej przyczyny, że on wcale nie byt zamordowany" [Gombrowicz 2010: 58] - powiada sędzia. I kilka zdań później sam do siebie, kontynuując monolog wewnętrzny: „Podniosłem palec do góry, zmarszczyłem brwi. Zbrodnia nie przychodzi sama, panowie, zbrodnię trzeba wypracować myślowo, obmyślić, wymyślić - pieczone gołąbki nie wpadają same do gąbki” [Gombrowicz 2010: 58]. Jaką właściwie zbrodnię ma na myśli w tym momencie sędzia? Tę, która nie nastąpiła, czy tę, która dopiero nastąpi, której sprawcą będzie sędzia, a obiektem młody mężczyzna, syn denata, Antoś?

Najwyraźniej jednak paranoiczny status narracji zdradza, jak już to zostało powiedziane, zakończenie opowiadania. Zgodnie z tradycyjną kompozycją powieści detektywistycznej (á la Agatha Christie) jest to ostateczna rozmowa pomiędzy śledczym (detektywem) a podejrzanymi, która ma dokonać ostatecznego i poznawczo zaskakującego odkrycia mordercy. Ostatnie strony Zbrodni z premedytacja zawierają rozmowę sędziego z jego głównym podejrzanym - Antonim. Zwróćmy uwagę na ramowy układ kompozycyjny: sędzia spotyka Antosia jako pierwszego po przybyciu do domostwa, a następnie niejako „dopada go" na samym końcu. Pomiędzy tymi dwoma scenami Antoś jest zazwyczaj ukryty, czy może inaczej, w języku Sedgwick, homospołeczne pragnienie realizuje się tu poprzez kobiece medium (jego siostrę i matkę), zatem w obiegu trójkątnym. Symboliczne stawki w tym obiegu albo go „feminizują” (w trójkącie sędzia-Cecylia-Antoś) albo „paternalizują” (w trójkącie sędzia-matka-Antoś). 
Prześledźmy kształt wygłosowej sekwencji wydarzeń. Do pokoju sędziego wchodzi Antoś, który słyszy, że jego ojciec został uduszony, a jedynie on sam miał „wolną drogę do ojca tej nocy”, jest zatem, nieco w logice kompleksu Edypa, mordercą. Sędzia uznaje również, że syn nie jest dostatecznie poruszony śmiercią ojca, nie uronił jednej łzy, a nawet się z tej śmierci cieszy. Szybko jednak okazuje się, że jest odwrotnie, syn kochał ojca.

- Dlaczego się pan tak wstydzi? Przecież śmierć ojca - to nic wstydliwego.

Wspominając ten moment, cieszę się, że wyszedłem bez szwanku - aczkolwiek nie poruszył się wcale.

- A może pan się wstydzi, bo pan kochał? Może naprawdę pan kochat?

Wyjąkał z trudem - z obrzydzeniem - z rozpaczą:

- Dobrze. Jeśli pan koniecznie ... jeśli... to tak, niech będzie... kochałem.

$[\ldots]$

- Kochał pan, dobrze, ale dlaczego w tej miłości tyle wstydu, tyle pogardy?

Zbladł, nic nie mówił.

- Tyle okrucieństwa, tyle wstrętu? Dlaczego pan ukrywa się z nią jak zbrodzień ze zbrodnią? Pan nie odpowiada? Pan nie wie? Może ja za pana będę wiedział. [Gombrowicz 2010: 77]

Jeśli w swej paranoicznej narracji sędzia podstawia siebie pod ojca, to lepiej zrozumiałe staną się kategorie takie jak „pogarda”, „wstręt” oraz ukrywanie się z miłością jak zbrodzień. Lepiej też będzie zrozumiałe „przyznanie się do winy” Antoniego. Warto dostrzec, że polega ona na niewłaściwym użyciu słów, jakby pomyłce. Bohater powiada zatem „pojechałem” zamiast „zrobiłem”, co początkowo zaskakuje samego sędziego, który nie rozumie komunikatu. Dopiero potem dostrzega, tak samo jak czytelnicy, że jest to sformułowanie, którego użył wcześniej sam sędzia do opisu morderstwa (,jazda na całego”). Zatem nie tyle przyznaje się on do winy, co - po początkowych wahaniach - uznaje (w sen- 
sie Heglowskiego Annerkenung) paranoiczny dyskurs sędziego; zaczyna używać jego słów i jego kategorii. Dlaczego tak się stało? Tuż przed tym dziwnym, literalnie pomyłkowym „przyznaniu się” Antoni, ciągle w dyskursie, czyli innymi słowy - aurze umysłu sędziego, miał coś dostrzec:

Być może w tej jednej sekundzie nienawiść ukazała mu się jako dopełnienie miłości, kto wie (to tylko moje przypuszczenie), czy w tym jednym mgnieniu oka nie dojrzał dwoistości strasznej wszelkiego uczucia - iż miłość i nienawiść są dwoma obliczami tego samego. [Gombrowicz 2010: 80]

Pamiętajmy o Freudowskiej teorii paranoi: opór wobec niekomunikowalnego „ja (mężczyzna) kocham go (mężczyznę)” realizuje się między innymi w psychozie paranoidalnej, której przekaz brzmi „nie kocham go, ja go nienawidzę, bo on mnie prześladuje”. Całą narrację sędziego można uznać za inwariantne rozwinięcie tego zdania. Antoni niejako uznaje tę paranoiczną narrację, używając pozornie pomyłkowego „pojechałem”. Niedługo potem sędzia doznaje regresji o mocno freudowskiej proweniencji „[...] stałem się nagle dzieckiem, małym bezradnym chłopczykiem i zapragnąłem starszemu bratu zwierzyć błąd i psotę" [Gombrowicz 2010: 82]. I wtedy wyjawia prawdę, przyznaje, że ojciec nie został zamordowany, bo nie ma śladów na jego szyi, po czym ucieka z pokoju, przebiega przez korytarz, wbiega do pokoju zmarłego i chowa się w szafie. Stamtąd słyszy coś, co zobaczy, jak tylko wyjdzie z ukrycia. Antoni zrobił dokładnie to, co w paranoicznej narracji sędziego miał zrobić: udusił (martwego) ojca. Zostawił zewnętrzne ślady. W odwróconej grze luster może to oznaczać nie tyle przyznanie się do winy, co współudział w „zbrodni przeciw naturze".

W tym miejscu interpretacji należy uczynić ważne zastrzeżenie. Zbyt łatwo można bowiem przyjąć, że Zbrodnia z premedytacja to paranoiczna opowieść o demonicznym homoseksualiście, który zabija obiekt swej miłości. Czy zresztą Schreber był homoseksualistą? Rzecz - wbrew pozorom - wcale nie jest oczywista. Jak pisze Sedgwick we wstępie do Between Men: 
[...] opisany przez Freuda przypadek doktora Schrebera pokazuje wyraźnie, jak wyparcie homoseksualnego pragnienia przez człowieka, który - według wszelkich zdroworozsądkowych standardów - był heteroseksualny, zaowocowało psychozą paranoiczną; jednak psychoanalityczny użytek zrobiony z tego odkrycia nie był zwrócony przeciw homofobii i jej schizogennej władzy, lecz przeciw homoseksualistom - w wyniku skojarzenia „homoseksualności” z chorobą psychiczną. [Sedgwick 2005: 186]

Istotnie, wszędobylską acz niewidoczną ramą, która okala tekst, jest instytucjonalna homofobia, bo to ona właśnie sprawia, że w Zbrodni z premedytacja paranoja staje się - nie wylącznie, ale w dużej mierze - formą miłości [Sedgwick 1986: XI].

\section{Bibliografia:}

Adler Alfred (1935), Homoseksualizm. Trening erotyczny i erotyczny odwrót, przeł. Tadeusz Fajans [pseud. Dr Taff], Warszawa.

Bartoszyński, Kazimierz (1984), O nieważności „tego, jak było naprawdę” („Zbrodnia z premedytacja” Witolda Gombrowicza), w: Gombrowicz i krytycy, wybór i oprac. Zdzisław Łapiński, Wydawnictwo Literackie, Kraków, s. 385-396.

Falkiewicz Andrzej (1984), Spór śledzącego i sprawcy, w: Gombrowicz i krytycy, wybór i opracowanie Zdzisław Łapiński, Wydawnictwo Literackie, Kraków.

Fik Ignacy (1961), Literatura choromaniaków, w: tegoż, Wybór pism krytycznych, oprac. Andrzej Chruszczyński, Książka i Wiedza, Warszawa, s.126-135.

Freud Sigmund (1996), Psychoanalityczne uwagi o autobiograficznie opisanym przypadku paranoi (dementia paranoides), w: tegoż, Charakter a erotyka, Dzieła t. II, przeł. Robert Reszke, Dariusz Rogalski, opr. Robert Reszke, Wydawnictwo KR, Warszawa, s. 105-165. Gombrowicz Witold (2010), Zbrodnia z premedytacja, w: tegoż, Bakakaj i inne opowiadania, Wydawnictwo Literackie, Kraków, s. 40-83.

Hocquenghem Guy (1978), Homosexual desire, przeł. Daniella Dangoor, Allison\&Busby, London [Wielka Brytania].

Hogg James (1969), Wyznania usprawiedliwionego grzesznika przez niego samego spisane, przeł. Anna Przedpełska-Trzeciakowska, PIw, Warszawa. 
Janion Maria (1975), Forma gotycka Gombrowicza, w: tejże, Gorączka romantyczna, PIW, Warszawa 1975, s. 165-243.

Jarzębski Jerzy (1982), Gra w Gombrowicza, PIW, Warszawa.

Kijowski Andrzej (1984), Strategia Gombrowicza, w: Gombrowicz i krytycy, wybór i opracowanie Zdzisław Łapiński, Wydawnictwo Literackie, Kraków.

Kristeva, Julia (2007), Potęga obrzydzenia. Esej o wstręcie, przeł. Maciej Falski, Wydawnictwo Uniwersytetu Jagiellońskiego, Kraków.

Laplanche Jean, Pontalis Jean-Bertrand (1996), Stownik psychoanalizy, przeł. Ewa Modzelewska, Ewa Wojciechowska, Wydawnictwa Szkolne i Pedagogiczne, Warszawa.

Legierski Michał (1996), Modernizm Witolda Gombrowicza. Wybrane zagadnienia, Almqvist\&Wiksell International, Stockholm [Szwecja].

Łapiński Zdzisław (1997), Ja Ferdydurke, Wydawnictwo Literackie, Kraków.

Margański Janusz (2001), Gombrowicz wieczny debiutant, Wydawnictwo Literackie, Kraków.

Schreber Daniel Paul (2006), Pamiętniki nerwowo chorego wraz z suplementami i aneksem, przel. Renata Darda-Staab, Libron, Kraków.

Sedgwick Eve Kosofsky (1985), Between Men. English Literature and Male Homosocial Desire, Columbia University Press, New York [Stany Zjednoczone].

Sedgwick Eve Kosofsky (1986), The Coherence of Gothic Conventions, Methuen, New York [Stany Zjednoczone].

Sedgwick Eve Kosofsky (2005), Męskie pragnienie homospołeczne i polityka seksualności, przeł. Adam Ostolski, „Krytyka Polityczna” nr 9/10, s. 93-103.

Sedgwick Eve Kosofsky (2014), Czytanie paranoiczne, czytanie reparacyjne albo: masz paranoję i pewnie myślisz, że ten tekst jest o tobie, przeł. Magda Szcześniak, „Widok. Teorie i praktyki kultury wizualnej" [online] $2014 \mathrm{nr} 5$ [dostęp: 14 lutego 2017] http:// pismowidok.org/index.php/one/article/view/184/299.

Szymutko Szymon (1993), Wielkość Gombrowicza. Natura i rytuał.

Na przykładzie „Zbrodni z premedytacja”, w: Znanym gościncem.

Prace poświęcone profesorowi Ireneuszowi Opackiemu, Katowice, s. 223-243.

Ziomek Jerzy (1990), Retoryka opisowa, Zakład Narodowy im. Ossolińskich, Wrocław. 


\section{Błażej Warkocki}

Crime incorporated. About the convention of "paranoid gothic” in Witold Gombrowicz's short story The Premeditated Crime.

The article presents the analysis and interpretation (in the form of a close reading) of Witold Gombrowicz's short story The Premeditated Crime from his debut collection Memoirs from a Time of Immaturity, 1933 (later published under the title Bakakaj or Bacacay in the English translation). The main theoretical framework is the concept of "paranoid Gothic” by Eve Kosofsky Sedgwick, which is based on the reinterpretation of Sigmund Freud's classic essay Psychoanalytical comments on autobiographically described paranoia. From that perspective Gombrowicz's narrative is interpreted as a paranoid homosexual narrative, and paranoia itself as a form of love.

Keywords: Gombrowicz; paranoid gothic; queer; Sedgwick; Freud.

Błażej Warkocki - adiunkt w Zakładzie Antropologii Literatury IFP UAM, krytyk literacki. Autor książki Homo niewiadomo. Polska proza wobec odmienności (Warszawa 2007), współautor (razem z P. Czaplińskim, E. Szybowicz, M. Lecińskim) Kalendarium życia literackiego 1976-20oo. Wydarzenia - dyskusje - bilanse (Kraków 2003), współredaktor (razem ze Z. Sypniewskim) Homofobii po polsku (Warszawa 2004) oraz (razem z A.W. Brzezińską, N. Bloch, M. Wosińską) zbioru reportaży Sztutowo/Stutthof. Gdzieś pomiędzy plażą a obozem (Warszawa 2013). Ostatnio opublikował książkę Różowy język. Literatura i polityka kultury na początku wieku (Warszawa 2013). Kontakt: warkocki@gmail.com. 